\title{
Transportes Transportation
}

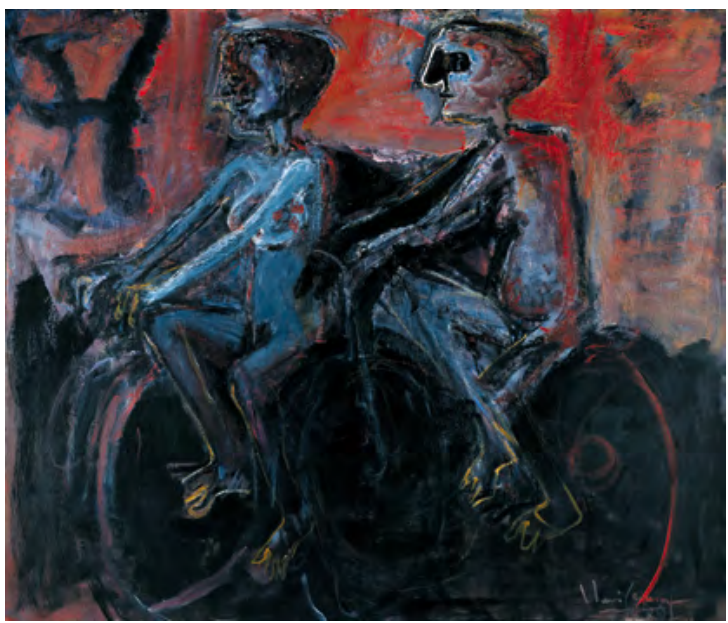

Ciclistas, 1989

Cyclists

Iberê Camargo 


\title{
Transportation
}

\author{
Márcio de Almeida D'Agosto' \\ Daniel Neves Schmitz Gonçalves ${ }^{2}$
}

Being a country of continental size, Brazil had three times increase in the movement passenger-kilometer - p.km - of passengers and 2.3 times increase in that of cargo - tonnes per $\mathrm{km}$ in a period of 30 years, between 1989 and 2018. In that period, the Brazilian Gross Domestic Product - GDP increased 5.5 times in absolute values and the population rose $45 \%$. As in all the world, cargo transportation in Brazil shows a strong correlation with the GDP and passenger transportation with the per capita GDP, since these activities, through their several modes, comprise essential resources for the economic and social development.

This chapter analyzes the recent evolution of the Brazilian transportation sector, showing the current scenario through the consolidation of data and historical information. It is based on the consolidated information from the Brazilian Institute of Geography and Statistics - IBGE, supported by the Freight Transport Laboratory - LTC of the Program of Transportation Engineering - PET of the Alberto Luiz Coimbra Institute for Graduate Studies and Research in Engineering - COPPE of the Federal University of Rio de Janeiro - UFRJ, according to the tables and figures attached to this text.

$\overline{1 \mathrm{PhD}}$ in Transportation Engineering from COPPE/UFRJ. Associate Professor at PET/COPPE/UFRJ and Coordinator of the LTC.

2 Master in Transportation Engineering from the Military Institute of Engineering - IME and doctoral candidate in Transportation Engineering from COPPE/UFRJ. Researcher at the LTC/PET/COPPE/UFRJ. 


\title{
Transportes
}

\author{
Márcio de Almeida D 'Agosto' \\ Daniel Neves Schmitz Gonçalves²
}

Sendo um país de dimensões continentais, no período de 30 anos, entre 1989 e 2018, o Brasil apresentou crescimento de três vezes na movimentação passageiro-quilômetro (p.km) de passageiros e de 2,3 vezes de cargas (toneladas por km). Neste período o Produto Interno Bruto (PIB) aumentou 5,5 vezes, em valores absolutos, e a população aumentou $45 \%$. Como em todo o mundo, no Brasil o transporte de cargas apresenta forte correlação com o PIB e o transporte de passageiros com o PIB per capta, porque estas atividades, por meio dos seus diversos modos, compõem recursos essenciais para o desenvolvimento econômico e social.

Este Capítulo analisa a evolução recente do setor de transportes brasileiro, apresentando o quadro atual por meio da consolidação de dados e informações históricas. Isso foi feito partindo de informações consolidadas pelo Instituto Brasileiro de Geografia e Estatística (IBGE) com o apoio do Laboratório de Transporte de Carga (LTC) do Programa de Engenharia de Transporte (PET) do Instituto Alberto Luiz Coimbra de Pós-Graduação e Pesquisa de Engenharia (COPPE) da Universidade Federal do Rio de Janeiro (UFRJ), conforme tabelas e figuras apresentadas em complemento ao texto.

1 Doutor em Engenharia de Transportes pela COPPE/UFRJ. Professor Associado do PET/ COPPE/UFRJ e Coordenador do LTC.

2 Mestre em Engenharia de Transportes pelo Instituto Militar de Engenharia (IME), doutorando em Engenharia de Transportes COPPE/UFRJ. Pesquisador do LTC/PET/COPPE/ UFRJ. 


\section{Overview of the modal division of transportation in Brazil}

Graph 15.1 shows the modal division of transportation in Brazil. It shows the predominance of the road mode for passenger transportation, with more than $91 \%$ of the transportation momentum (p.km) being carried out through this mode, whereas water and railway transportation, together, do not reach $2.0 \%$ and air transportation reaches $6.6 \%$, even considering that it covers longer distances. On the other hand, the modal division of cargo transportation is less unbalanced, with about 58\% carried out through the road mode, $29 \%$ through railways and $13 \%$ through the other modes, being the smallest parcel $(0.1 \%)$ through the air mode, which is usually the most expensive one. It is important to highlight that the participation of the railway mode has been about $26 \%$ over the last five years. It happens that the activity and thus the participation of the road and water modes significantly dropped due to the economic downturn.

Since the 1950s, the historical predominance of road transportation in the movement of passengers and cargo, in a country of continental size like Brazil, has led to the rise of transportation costs, which impacts on the logistical costs and, thus, on the increase of the final prices of products. This situation also leads to the excessive consumption of fossil fuels, a non-renewable source of energy that emits carbon dioxide, mainly greenhouse gas, responsible for the increase of the global warmth, the major global environmental challenge of the 21st century. In the cities, the burn of fossil fuels by transportation can be considered the major source of air pollutants, responsible for health problems in the residents, like diseases of the respiratory, cardiovascular and neurological systems.

To balance the modal division of the transportation, using more the railway and water modes - inland and coastal navigation - for cargo and using more the railway mode for passengers, is a need which is related to the intense and constant application of investments in the infrastructure required to improve the supply of those modes which have a higher cost of implementation and a lower cost of operation and maintenance, compared with the road mode.

\section{Profile of road transportation}

Based on the consolidated data of vehicle licensing annually published by the Brazilian Association of Motor Vehicle Manufacturers - ANFAVEA, adjusted by means of scrapping curves revised by Gonçalves, Goes e D'Agosto (2019), it is estimated that the fleet of Brazilian cars and 


\section{Panorama da divisão modal dos transportes no Brasil}

O Gráfico 15.1 apresenta a divisão modal dos transportes no Brasil. Nele se verifica predominância do modo rodoviário para o transporte de passageiros, com mais de 91\% do momento de transporte (p.km) sendo realizado por este modo, enquanto o transporte aquático e ferroviário somados não chegam a representar 2,0\% e o transporte aéreo, mesmo considerando que se realiza a maiores distâncias, atinge $6,6 \%$. Por outro lado, a divisão modal do transporte de cargas é menos desequilibrada, com cerca de $58 \%$ realizado pelo modo rodoviário, $29 \%$ por ferrovias e $13 \%$ pelos demais modos, com a menor parcela $(0,1 \%)$ pelo modo aéreo, usualmente o mais caro. É importante salientar que a participação nos últimos cinco anos do modo ferroviário é de cerca de $26 \%$. Ocorre que a atividade, e consequentemente a participação dos modos rodoviário e aquático caíram significativamente devido à recessão.

Desde a década de 1950, a predominância histórica do transporte rodoviário na movimentação de passageiros e cargas, num país de extensão continental como o Brasil, conduz à elevação dos custos de transporte, que impacta nos custos logísticos e consequentemente no aumento dos preços finais dos produtos. Esta situação também leva ao consumo excessivo de combustíveis fósseis, fonte não renovável de energia com consequente emissão de dióxido de carbono, principal gás de efeito estufa, responsável pelo agravamento do aquecimento global, principal desafio ambiental global do Século XXI. Nas cidades, a queima de combustíveis fósseis pelos transportes pode ser considerada como a principal fonte de poluentes atmosféricos, responsáveis por problemas de saúde nos residentes, como doenças do sistema respiratório, cardiovascular e neurológicas.

Equilibrar a divisão modal dos transportes, por meio de maior utilização dos modos ferroviário e aquático (navegação interior e navegação marítima de cabotagem) para carga, e do modo ferroviário para os passageiros, é uma necessidade que está relacionada com a aplicação constante e intensa de investimentos em infraestrutura necessária à ampliação da oferta destes modos que apresentam maior custo de implantação e menores custos de operação e manutenção, se comparados ao modo rodoviário.

\section{O perfil do transporte rodoviário}

Com base nos dados consolidados de licenciamento de veículos publicados anualmente pela Associação Nacional dos Fabricantes de Veículos Automotores (ANFAVEA), ajustados por meio de curvas de sucateamento revisada por Gonçalves, Goes e D'Agosto (2019), estima-se que no período de 1980 a 2018, a frota de automóveis 
light commercial vehicles has risen 5.1 times in the period between 1980 and 2018. In this same period, the fleet of trucks tripled and the fleet of buses, either for urban use or for interstate and international transportation, increased 3.3 times. Moreover, the fleet of motorcycles dramatically increased 68 times.

It is estimated that, in this period, the fleet of cars and light commercial vehicles changed from slightly more than nine million to nearly 46 million vehicles, placing Brazil with about five inhabitants per vehicle, a rate still far from those reached in developed countries, which record figures between one and two inhabitants per vehicle. The United States stand out with a stable value of 1.2 inhabitants per vehicle between 2001 and 2015 .

Beyond the boost received in the period of economic upturn and better income distribution, which occurred in the first decade of the 21st century, the increase in the fleet of cars and light commercial vehicles in Brazil was due to the incentive given by the federal government to the car industry between 2012 and December 2014, the reduction of the rate of the Excise Tax on Industrialized Products - IPI. The difference in the inhabitants per vehicle relation when comparing Brazil with the other countries listed in Graph 15.2 is due to the low per capita income of most of its population. Hitting a level like that of the United States is quite questionable, however, considering the aspects already presented concerning the waste of energy resources and the environmental impacts stemmed from the excessive use of individual motor transportation.

In the case of trucks, the most significant increases were in the classes of light commercial vehicles (total gross weight - TGW between 6 and 10 tonnes) and heavy-duty trucks (TGW higher than or equal to 15 tonnes or combined total gross weight CTGW higher than or equal to 40 tonnes), which demonstrates a better specialization of the road transportation of cargo, through the adaptation of the vehicles to urban use (light commercial vehicles) and to long-distance transfers (heavy-duty trucks).

Based on a survey from the National Confederation of Transportation CNT, Table 15.1 shows the profile of the Brazilian road network and the big challenge that Brazil faces in implementing road transportation considering that only $13.7 \%$ of its roads are paved. This situation is not supposed to change in the short term, considering that slightly more than a $10 \%$ increase in the road network is planned to be implemented in a time horizon not yet established by the government. 
e comerciais leves brasileiros tenha crescido 5,1 vezes. Neste mesmo período a frota de caminhões triplicou e a frota de ônibus, tanto para uso urbano quanto para o transporte interestadual e internacional, aumentou 3,3 vezes. Além disso, houve um aumento vertiginoso de 68 vezes na frota de motocicletas.

Estima-se que no período a frota de automóveis e veículos comerciais leves tenha passado de pouco mais de nove milhões para quase 46 milhões de veículos, colocando o Brasil com aproximadamente cinco habitantes por veículo, taxa ainda distante das obtidas para os países desenvolvidos, que apresentam valores entre um e dois habitantes por veículo e onde os Estados Unidos se destacam com valor estável de 1,2 habitantes por veículo entre 2001 e 2015.

Além do impulso recebido no período de crescimento econômico e melhor distribuição de renda, que ocorreu na primeira década do Século XXI, o aumento da frota de automóveis e veículos comerciais leves no Brasil deveu-se ao incentivo dado pelo governo federal à indústria automobilística entre 2012 e dezembro de 2014, por meio da redução da alíquota do Imposto Sobre Produtos Industrializados (IPI). A diferença na relação habitantes por veículo, quando se compara o Brasil com os demais países listados no Gráfico 15.2, deve-se à baixa renda per capita da grande maioria da sua população, muito embora atingir níveis como os dos Estados Unidos sejam bastantes questionáveis se considerados os aspectos já apresentados quanto ao desperdício de recursos energéticos e aos impactos ambientais oriundos do excessivo uso do transporte individual motorizado.

No caso dos caminhões, os aumentos mais expressivos se deram nas classes de caminhões leves (peso bruto total (PBT) entre 6 e 10 toneladas) e pesados (PBT maior ou igual a 15 toneladas ou peso bruto total combinado (PBTC) maior ou igual a 40 toneladas) o que demonstra uma melhor especialização do transporte rodoviário de cargas, por meio da adequação dos veículos ao uso urbano (veículos leves) e as transferências de longa distância (veículos pesados).

Com base em levantamento da Confederação Nacional dos Transportes (CNT), a Tabela 15.1 mostra o perfil da malha rodoviária brasileira e o grande desafio que o País enfrenta em efetivar o transporte rodoviário tendo em vista que apenas 13,7\% da extensão de suas rodovias são pavimentadas. Esta situação parece que não vai se alterar no curto prazo, tendo em vista os pouco mais de $10 \%$ de extensão de rodovias planejadas com previsão de implantação em um horizonte não definido pelo governo. 
The profile of the road transportation shows the critical situation of this important transportation mode and the compelling need of huge and continuous investments in the road infrastructure, aiming at improving its quality and expanding the road network.

\section{Profile of railway transportation}

Table 15.2 shows that the three concessionary railways with the highest useful tonne transported per kilometer - TKU, a measurement defined as the net transported cargo (tonne) times the distance covered $(\mathrm{km})$, add up to more than $3 / 4$ of the total transported in 2016 (81\%). They are: Carajás Railway - EFC (39.9\%), Vitória to Minas Railway - EFVM (21.9\%) and MRS Logística S.A. (19.2\%). It is important to highlight that more than $2 / 3$ of the cargo is ore, being transported by more efficient railways in terms of cost (R\$/TKU) and energy use in megajoules per tonne-kilometer (MJ/t.km).

Concerning the railway transportation of passengers in the same year under analysis (2016), it is noticed that $87 \%$ (p.km) and more than half of the operation line are in the Metropolitan Areas of São Paulo and Rio de Janeiro, which demonstrates its concentration in the major Brazilian cities and the poor dissemination of this transportation mode in the other metropolises.

\section{Profile of waterway transportation}

Waterway transportation accounts for only $9.3 \%$ of the cargo transported in Brazil, despite the large amount and extension of the Brazilian rivers and nearly $8,500 \mathrm{~km}$ of coast. The extension of the waterway network corresponds to $2.7 \%$ of the road network in Brazil, adding up to $41,795 \mathrm{~km}$, of which only $47 \%$ is economically used. This occurs either because the path of the rivers passes through areas with low productive potential or because of the low depth of the riverbeds, with long, though very winding, paths.

Inland navigation has a participation of about $1.0 \%$ in the modal division and more than half of the cargo transported in 2018 was dry bulk, distributed among agricultural (soybean $43 \%$, corn $25 \%$ and soybean bran $4.0 \%$ ) and non-agricultural (iron ore $12 \%$ and sand $7.0 \%$ ).

Unlike inland navigation, in which the transportation is divided into several groups of goods, three groups prevail in coastal navigation: fuels and mineral oils, bauxite and containers. Together, they accounted for more than $88 \%$ of the 163 million tonnes transported 
O perfil do transporte rodoviário apresentado demonstra a situação crítica deste importante modo de transporte e a premente necessidade de investimentos pesados e contínuos em infraestrutura viária, com melhoria da qualidade e ampliação da malha rodoviária.

\section{O perfil do transporte ferroviário}

Verifica-se na Tabela 15.2 que as três concessionárias com maior tonelada por quilômetro útil (TKU), medida definida pelo produto da carga líquida transportada (tonelada) pela distância percorrida $(\mathrm{km})$, somam mais de $3 / 4$ do total transportado em 2016 (81\%), são elas: Estrada de Ferro Carajás (EFC) (39,9\%), Estrada de Ferro Vitória a Minas (EFVM) (21,9\%) e a MRS Logística S.A. (19,2\%). É importante ressaltar que mais de $2 / 3$ da carga movimentada é de minério, sendo transportados por ferrovias mais eficientes em termos de custo (R\$/TKU) e uso de energia em megajoules por tonelada-quilômetro (MJ/t.km).

No tocante ao transporte ferroviário de passageiros, para o mesmo ano de análise (2016), observa-se que $87 \%$ (p.km) e mais da metade da linha operacional encontram-se nas Regiões Metropolitanas de São Paulo e do Rio de Janeiro, o que demonstra a concentração nas grandes cidades brasileiras e pouca difusão deste modo de transporte nas outras metrópoles nacionais.

\section{O perfil do transporte aquático}

O transporte aquático representa apenas 9,3\% das cargas transportadas no Brasil, apesar da grande quantidade e extensão dos rios brasileiros e dos quase $8500 \mathrm{~km}$ de costa. A extensão da malha hidroviária corresponde a 2,7\% da malha rodoviária do Brasil, com total de 41795 km, onde só $47 \%$ são utilizadas economicamente. Isto se dá ou porque o trajeto dos rios passa por áreas com baixo potencial produtivo, ou devido à baixa profundidade do leito, com traçado extenso, mas muito sinuoso.

A navegação interior possui uma participação de aproximadamente 1,0\% na divisão modal, e mais da metade da carga transportada em 2018 foi granel sólido, distribuindo-se entre agrícola (soja $43 \%$, milho $25 \%$ e farelo de soja $4,0 \%$ ) e não agrícola (minério de ferro $12 \%$ e areia $7,0 \%$ ).

Diferente da navegação interior, onde o total transportado divide-se em diversos grupos de mercadoria, na navegação de cabotagem existe a predominância de três grupos: os combustíveis e óleos minerais, a bauxita e os contêineres. Juntos, foram responsáveis por mais de $88 \%$ dos 163 milhões de toneladas transportadas 
in 2018. Their participation in the modal division varied from $8.2 \%$ to $14.4 \%$ in the last 10 years. Their current participation is $8.6 \%$.

Waterway transportation (of passengers) is responsible for about $0.05 \%$ of the national transportation of passengers. Most of it is in the Amazon region, where waterway transportation is the most important transportation means; and in the Metropolitan Area of Rio de Janeiro.

\section{Profile of air transportation}

Air transportation has shown a small participation in the movement of cargo in Brazil, with $0.11 \%$ of the total in 2018. On the other hand, its share in the modal division has risen in transportation of passengers, reaching $6.6 \%$. Graph 15.4 shows the number of domestic and international flights between 2009 and 2018, pointing out to an increase between 2009 and 2012 (35\%). That trend fell in 2013 , confirmed by five consecutive years of decreasing number of domestic flights in Brazil; and there was a sign of increase in 2018 (1.0\%). Conversely, the number of international flights increased $43 \%$ (2009-2014), followed by an average drop of $7.0 \%$ for three consecutive years and an upturn of $11 \%$ in 2018.

Assessing only the number of flights is a superficial way to establish the evolution of the air mode. The evolution of the transportation momentum should also be checked (p.km and t.km) in the period. Table 15.4 shows these data and points out the significant increase of the activity in the period under analysis, both in the transportation of passengers (79\%) and of cargo (56\%).

\section{Profile of pipeline transportation}

Beyond the transportation of water, the largest network of pipeline transportation in the world and that belongs to the sector of sanitation, pipeline transportation all over the world is only carried out for a very specialized fraction of cargo, highlighted by fluids (petroleum, fuels derived from petroleum and biofuels, like ethanol) and natural gas. Due to its specialization, pipeline transportation corresponds to about $3.3 \%$ of the activity of cargo transportation, divided into oil (64\%), gas (12\%) and ore (26\%) pipelines. 
em 2018. Sua participação na divisão modal variou entre $8,2 \%$ a $14,4 \%$, nos últimos 10 anos. Atualmente sua participação é de 8,6\%.

O transporte aquático de passageiros é responsável por cerca de $0,05 \%$ do transporte nacional de passageiros. A maior parte desse transporte se dá na região amazônica, onde é o mais importante meio de transporte e na Região Metropolitana do Rio de Janeiro.

\section{O perfil do transporte aéreo}

O transporte aéreo tem apresentado uma pequena participação na movimentação de cargas no Brasil, com 0,11\% do total em 2018. Por outro lado, sua participação na divisão modal tem crescido no transporte de passageiros, chegando a 6,6\%. O Gráfico 15.4 apresenta o número de voos domésticos e internacionais entre os anos de 2009 e 2018 e percebe-se o aumento entre 2009 e 2012 (35\%). Em 2013 , houve uma redução nessa tendência, confirmada por cinco anos consecutivos de decréscimo do número de voos domésticos no Brasil e um sinal de acréscimo em 2018 (1,0\%). Por outro lado, o número de voos internacionais apresentou um crescimento de 43\% (2009-2014), seguido de uma queda em média de 7,0\% por três anos consecutivos e uma retomada de 11\% em 2018.

Avaliar apenas o número de voos torna-se superficial para determinar a evolução do modo aéreo. É preciso verificar também evolução do momento de transporte (p.km e t.km) no período. A Tabela 15.4 apresenta esses dados e permite verificar o crescimento expressivo da atividade no período analisado, tanto no transporte de passageiros (79\%) como no de carga (56\%).

\section{O perfil do transporte por dutos}

Além do transporte de água, maior rede de transporte dutoviário no mundo e que se posiciona no setor de saneamento, no mundo todo o transporte por dutos se dá apenas para uma fração muito especializada de cargas, onde se destacam os líquidos (petróleo, combustíveis derivados de petróleo e biocombustíveis, como o etanol) e o gás natural. Em função da sua especialização, o transporte dutoviário corresponde por cerca de $3,3 \%$ da atividade do transporte de carga, dividido em oleodutos (64\%), gasodutos (12\%) e minerodutos (26\%). 


\section{Final remarks}

Transportation fosters the economic and social development and it plays a key role in the progress of the nations. The historical association of the evolution of the transportation momentum with the GDP shows that the desired return of the economic growth in Brazil will boost the transportation activity over the next years. Nevertheless, the predominance of the road mode in the modal division of transportation leads to higher costs, energy consumption and environmental impacts when compared with other modes, like railway and waterway transportation, mainly in countries of continental size like Brazil. To reverse this scenario, investments should be directed to the infrastructure that favors active transportation (hiking and cycling), collective road transportation (buses, bus rapid transit - BRT and bus rapid systems - BRS) and mass transportation (subways and trains) for the transportation of passengers in the urban areas, as well as high capacity transportation (railways, inland and coasting navigation) for the transportation of cargo, improving its use for shipping containers. In addition, attention should be given to the improvement, maintenance and conservation of the road network, whose performance does not match the importance of the role it plays.

\section{Reference}

GONÇALVES, D. N. S.; GOES, G. V.; D'AGOSTO, M. A. Transportes no Brasil: panorama e cenários prospectivos para atendimento da contribuição nacionalmente determinada. Rio de Janeiro: Instituto Brasileiro de Transporte Sustentável, 2019.

Translated by: La-Fayette Côrtes Neto 


\section{Considerações finais}

O transporte é uma atividade indutora de desenvolvimento econômico e social e tem papel fundamental para o progresso das nações. A histórica associação da evolução do momento de transporte com o PIB demonstra que o desejável retorno ao crescimento econômico do Brasil dinamizará a atividade de transporte nos próximos anos. Porém, a predominância do modo rodoviário na divisão modal do transporte conduz a maiores custos, consumo de energia e impactos ambientais se comparado a outros modos, como o ferroviário e aquático, principalmente em países de dimensões continentais como o Brasil. Reverter este quadro passa por direcionar investimentos em infraestrutura que privilegiem os transportes ativos (caminhada e ciclismo), rodoviários coletivos (ônibus, bus rapid transit (BRT) e bus rapid systems (BRS)) e de massa (metrôs e trens) para o transporte de passageiros nas áreas urbanas, bem como o transporte de maior capacidade (ferrovias, navegação interior e navegação marítima de cabotagem) para o transporte de cargas, ampliando seu uso para o embarque da carga geral conteinerizada. Adicionalmente, atenção deve ser dada à ampliação, manutenção e conservação da rede de rodovias cujo desempenho não faz justiça à importância do papel que desempenha.

\section{Referência}

GONÇALVES, D. N. S.; GOES, G. V.; D'AGOSTO, M. A. Transportes no Brasil: panorama e cenários prospectivos para atendimento da contribuição nacionalmente determinada. Rio de Janeiro: Instituto Brasileiro de Transporte Sustentável, 2019. 
Tabela 15.1 - Extensão das malhas viárias do País - 2018

Table 15.1 - Extension of transportation networks in Brazil - 2018

\begin{tabular}{cc}
$\begin{array}{c}\text { Especificação/ } \\
\text { Item }\end{array}$ & $\begin{array}{c}\text { Extensão das malhas viárias }(\mathrm{km}) / \\
\text { Extension of transportation network }(\mathrm{km})\end{array}$ \\
\hline
\end{tabular}

Malha rodoviária/Road network

Federal/Federal 76454

Pavimentada/Paved 65615

Não pavimentada/Unpaved

10839

Estaduais Transitórias, Estaduais e Municipais/

1486938

Temporary State Roads, State and Municipal Roads

Pavimentada/Paved

147838

Não pavimentada/Unpaved

1339100

Rede Planejada/Planned Network

157309

Malha ferroviária/Railway network

Nacional /National

Concedida/Granted

29074

Malha hidroviária/Waterway network

Rede fluvial nacional/National river network

41795

Vias utilizadas economicamente/Economic exploited waterwc

19464

Fonte/Source: Boletim estatístico [da Confederação Nacional dos Transportes]. Brasília, DF: CNT, ago. 20 Disponível em/Available from: <http://www.cnt.org.br/boletim/boletim-estatistico-cnt $>$. Acesso em: jan. 2019 /Cited: Jan. 2019.

Nota: Até agosto de 2018/Note: Until August 2018. 


\section{Tabela 15.2 - Dados gerais do transporte ferroviário - 2016-2017}

Table 15.2 - General data of railway transportation - 2016-2017

\begin{tabular}{|c|c|c|c|c|c|c|c|c|}
\hline \multirow[t]{2}{*}{$\begin{array}{c}\text { Concessionárias/ } \\
\text { Concessionary railways }\end{array}$} & \multicolumn{2}{|c|}{$\begin{array}{l}\text { Carga transportada } \\
\text { (mil toneladas) } \\
\text { (tu)/ } \\
\text { Transported freight } \\
\text { (thousand tonnes) }\end{array}$} & \multicolumn{2}{|c|}{$\begin{array}{l}\text { Locomotivas/ } \\
\text { Locomotives }\end{array}$} & \multicolumn{2}{|c|}{$\begin{array}{c}\text { Vagões/ } \\
\text { Freight } \\
\text { cars }\end{array}$} & \multicolumn{2}{|c|}{$\begin{array}{l}\text { Carga transportada } \\
\text { x km útil (mil } \\
\text { toneladas) (tku)/ } \\
\text { Transported freight } x \\
\text { km (thousand } \\
\text { tonnes)(tku) }\end{array}$} \\
\hline & 2016 & 2017 & 2016 & 2017 & 2016 & 2017 & 2016 & 2017 \\
\hline \multicolumn{9}{|l|}{ América Latina Logística } \\
\hline Malha Norte S.A & 14906 & 859 & 142 & 142 & 3847 & 3847 & 22998 & 1325 \\
\hline \multicolumn{9}{|l|}{ América Latina Logística } \\
\hline Malha Oeste S.A & 3505 & 277 & 45 & 45 & 831 & 831 & 797 & 40 \\
\hline \multicolumn{9}{|l|}{ América Logística Malha } \\
\hline Paulista S.A & 6013 & 438 & 276 & 276 & 5515 & 5515 & 4556 & 359 \\
\hline \multicolumn{9}{|l|}{ América Latina Logística } \\
\hline Malha Sul S.A & 18345 & 1079 & 364 & 364 & 9525 & 9525 & 11831 & 664 \\
\hline Estrada de Ferro Carajás & 155252 & 14089 & 307 & 307 & 17853 & 17853 & 136268 & 12357 \\
\hline \multicolumn{9}{|l|}{ Ferrovia Paraná Oeste } \\
\hline S.A & 440 & 31 & 15 & 15 & 504 & 504 & 131 & 14 \\
\hline \multicolumn{9}{|l|}{ Estrada de Ferro Vitória } \\
\hline a Minas & 129601 & 11042 & 318 & 318 & 18738 & 18738 & 74559 & 6386 \\
\hline \multicolumn{9}{|l|}{ Ferrovia Centro- } \\
\hline Atlântica S.A. & 24993 & 1681 & 578 & 578 & 17593 & 17593 & 19045 & 1014 \\
\hline \multicolumn{9}{|l|}{ Ferrovia Norte-Sul } \\
\hline Tramo Norte & 5029 & 205 & 17 & 17 & 3025 & 3025 & 4454 & 164 \\
\hline \multicolumn{9}{|l|}{ Ferrovia Tereza Cristina } \\
\hline S.A. & 2898 & 232 & 17 & 17 & 443 & 443 & 224 & 18 \\
\hline \multicolumn{9}{|l|}{ Transnordestina } \\
\hline Logística S.A & 1320 & 107 & 99 & 99 & 1769 & 1769 & 652 & 52 \\
\hline MRS Logística S.A. & 141501 & 10342 & 757 & 757 & 11224 & 11224 & 65646 & 4743 \\
\hline
\end{tabular}

Fonte/Source: Evolução do transporte ferroviário de cargas. Brasília, DF: Agência Nacional de Transportes Terrestres, 2017. Disponível em/Available from: <http://portal.antt.gov.br/index.php/content/view/1588 html>. Acesso em: jan. 2019/Cited: Jan. 2019.

Nota: Até janeiro de 2016/2017./ Note: Until January 2016/2017. 
Tabela 15.3 - Movimento de carga, por tipo de navegação - 2010-2018 Table 15.3 - Cargo transportation by modal of navigation - 2010-2018

\begin{tabular}{|c|c|c|c|}
\hline \multirow{2}{*}{$\begin{array}{l}\text { Anos / } \\
\text { Years }\end{array}$} & \multicolumn{3}{|c|}{ Movimento de carga (1 $000 \mathrm{t}) /$ Cargo movement $(1,000 \mathrm{t})$} \\
\hline & $\begin{array}{l}\text { Longo curso/ } \\
\text { Deep sea }\end{array}$ & $\begin{array}{l}\text { Cabotagem/ } \\
\text { Cabotage }\end{array}$ & $\begin{array}{c}\text { Outras navegações/ } \\
\text { Others }\end{array}$ \\
\hline 2010 & 613009 & 185657 & 31991 \\
\hline 2011 & 657677 & 193449 & 34428 \\
\hline 2012 & 670479 & 201398 & 32519 \\
\hline 2013 & 684162 & 204742 & 40443 \\
\hline 2014 & 713582 & 212991 & 42298 \\
\hline 2015 & 753340 & 212712 & 42207 \\
\hline 2016 & 741557 & 212393 & 44118 \\
\hline 2017 & 803268 & 221840 & 60974 \\
\hline 2018 & 822806 & 230592 & 64068 \\
\hline
\end{tabular}

Fonte/Source: Anuário estatístico aquaviário 2018. Brasília, DF: Agência Nacional de Transportes Aquaviários, [2019]. Disponível em/Available from : <http://web.antaq.gov.br/anuario/>. Acesso em: jan. 2019/ Cited: Jan . 2019.

\section{Gráfico 15.1 - Matriz de transporte de passageiros e cargas, por modalidades - Brasil - 2018 \\ Graph 15.1 - Matrix of passenger and cargo tranportation by mode - Brazil - 2018}

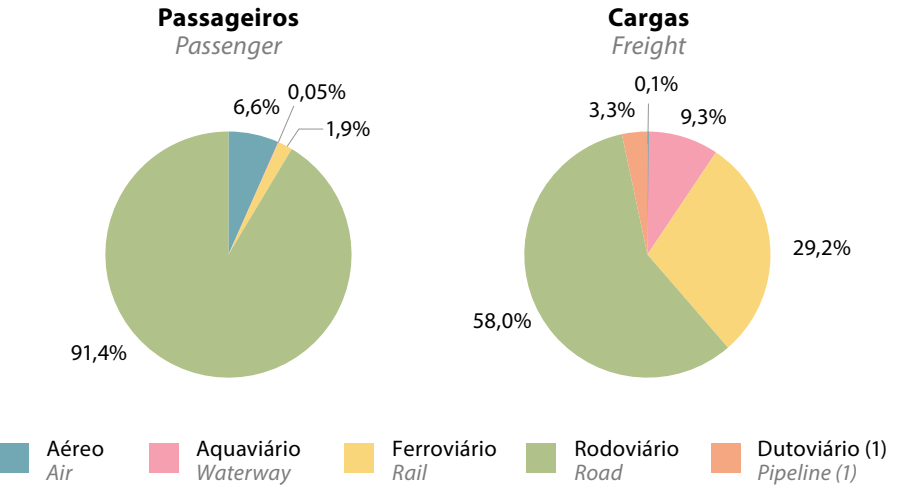

Fonte/Source: Boletim estatístico [da Confederação Nacional dos Transportes]. Brasília, DF: CNT, out. 2017. Disponível em/Available from: <http://www.cnt.org.br/boletim/boletim-estatistico-cnt>.

Acesso em: abr. 2018/Cited: Apr. 2018.

(1) Não se aplica a transporte de passageiros./ (1) Not applicable to passenger transportation. 
Gráfico 15.2 - Habitantes por autoveículo em alguns países - 2001/2015

Graph 15.2 - Inhabitants per vehicle in selected countries - 2001/2015

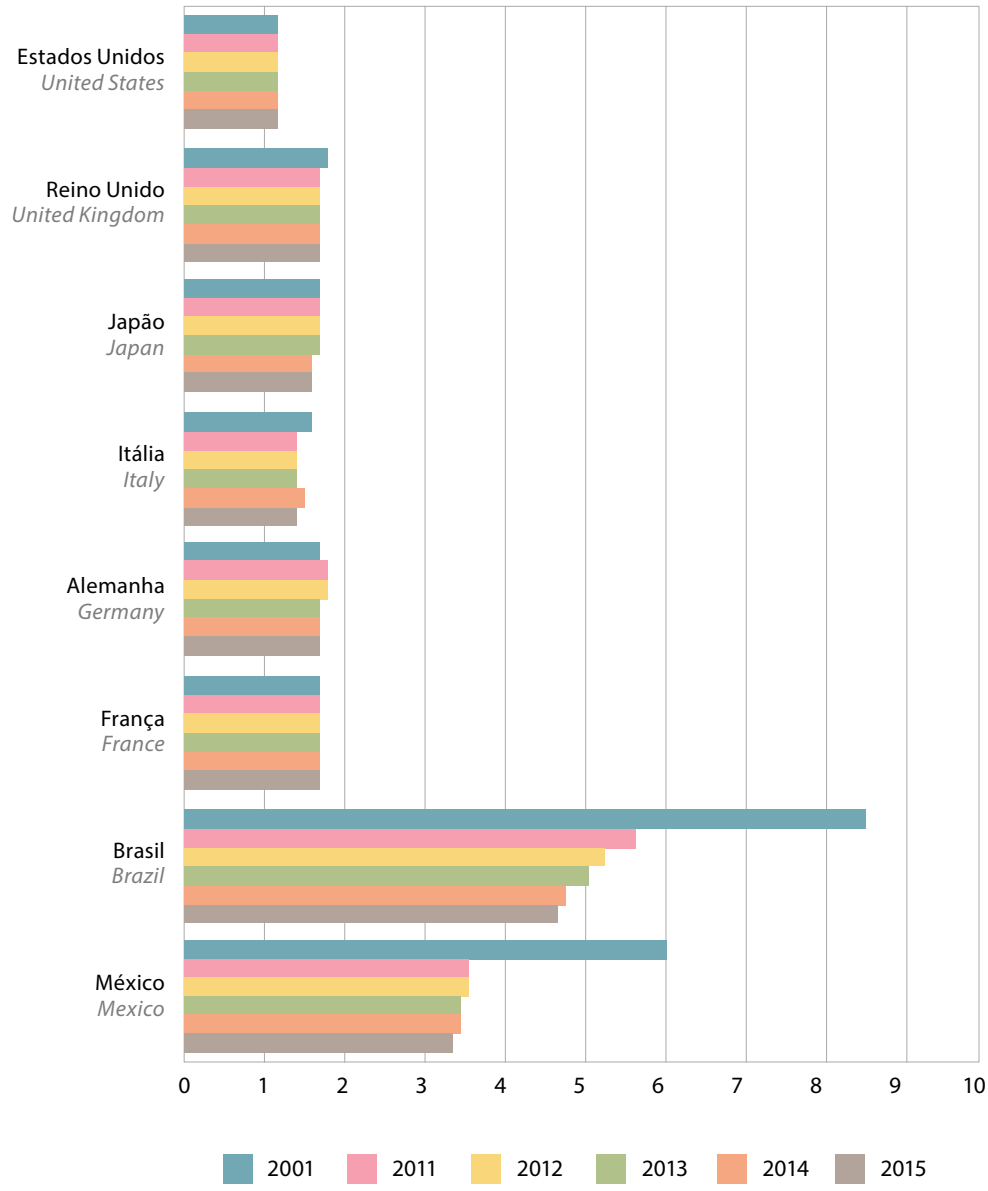

Fonte/Source: Anuário da indústria automobilística brasileira 2017. São Paulo: Associação Nacional dos Fabricantes de Veículos Automotores, 2017. Disponível em/Available from:

<http://www.virapagina.com.br/anfavea2017>. Acesso em: jan. 2019/Cited: Jan. 2019. 
Gráfico 15.3 - Movimento de carga, por tipo de navegação - 2010-2018

Graph 15.3 - Cargo transportation by modal of navigation - 2010-2018

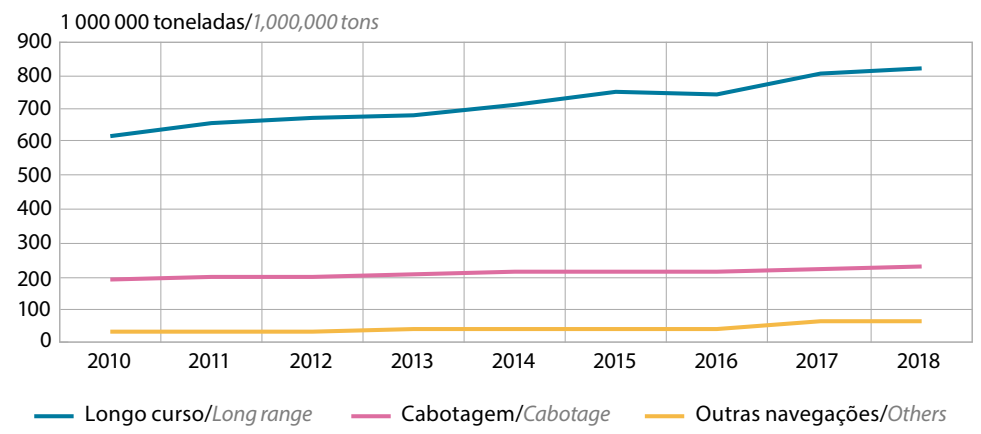

Fonte/Source: Anuário estatístico aquaviário 2018. Brasília, DF: Agência Nacional de Transportes Aquaviários, [2019]. Disponível em/Available from: <http://web.antaq.gov.br/anuario/>.Acesso em: feb. 2019/Cited: Feb. 2019.

\section{Gráfico 15.4 - Evolução da quantidade de voos - 2009-2018}

Graph 15.4 - Evolution of the number of flights - 2009-2018

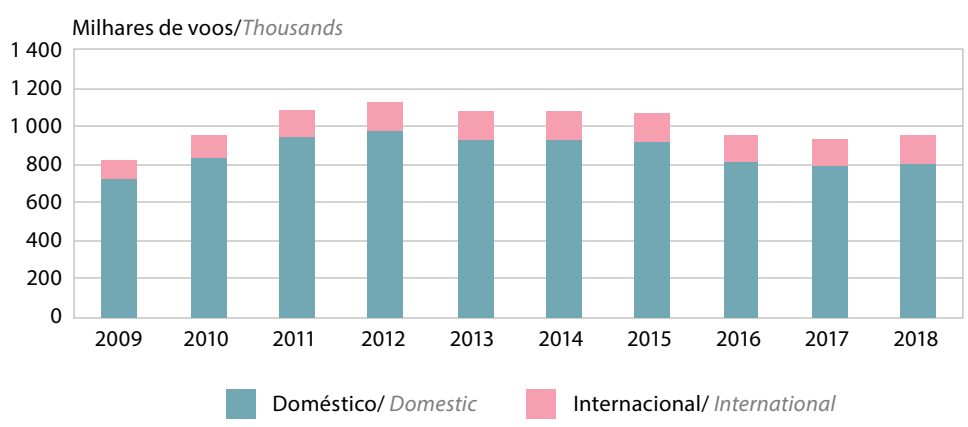

Fonte/Source: Agência Nacional de Aviação Civil (ANAC). 


\section{Gráfico 15.5 - Evolução da quantidade de passageiros transportada}

2009-2018

Graph 15.5 - Evolution of the number of passengers transported - 2009-2018

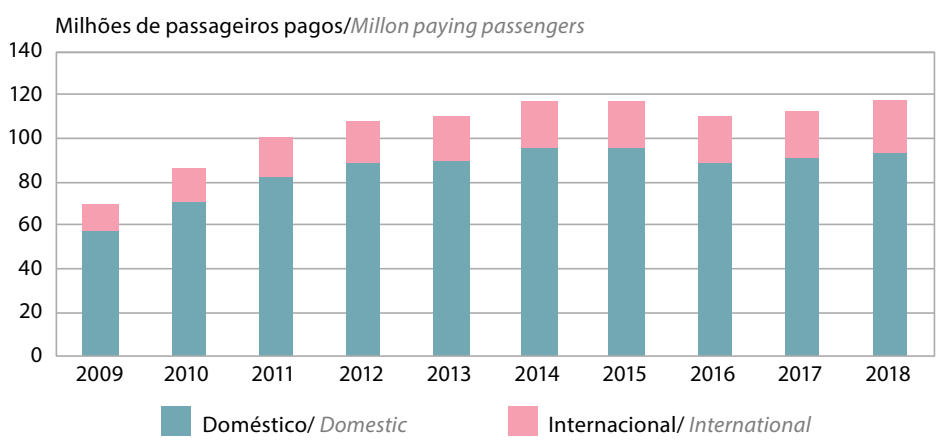

Fonte/Source: Agência Nacional de Aviação Civil (ANAC).

\section{Gráfico 15.6 - Carga aérea transportada - 2009-2018}

Graph 15.6 - Air cargo transported - 2009-2018

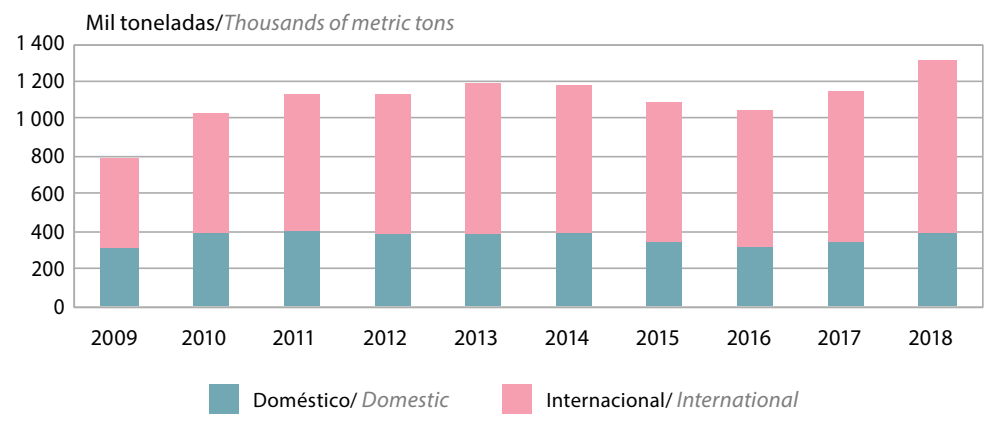

Fonte/Source: Agência Nacional de Aviação Civil (ANAC). 